\title{
NEW EVIDENCE ON FDI DETERMINANTS: AN APPRAISAL OVER THE TRANSITION PERIOD
}

\author{
Yulia Gorbunova, Davide Infante, Janna Smirnova*
}

\begin{abstract}
:
The aim of this work is to provide new evidence on the factors that determine the flow of FDI among transition countries. The analysis takes into consideration the period of most intense transition and post-transition (1994-2002) of 26 former socialist countries. The empirical estimates enable us to draw two main conclusions: first classical locational FDI factors maintain their role in the context of transition countries, and, second, that FDI are influenced by specific market and institutional factors. Among market variables, relatively higher labour costs surprisingly do not constitute an obstacle for foreign investment. We find that variables reflecting market stabilising institutions play a more important role than those representing market creating institutions. Although, there is a certain tolerance of foreign investors towards weak institutional environment, we demonstrate that, to attract FDI, countries should reinforce their macroeconomic stability by focusing on market stabilising institutions.
\end{abstract}

Keywords: foreign direct investment, transition countries, market institutions

JEL Classification: C33, F21, F23, P27

\section{Introduction}

Foreign direct investments (FDI) are an important source of private capital since they are directed towards productive activities, and therefore contribute greatly to economic development. FDI play an especially important role in countries shifting towards a market economy, for two reasons. Firstly, FDI represent imports of direct capital and new technologies, thus contributing to strategic re-organization of firms (Konings, 2000; Yudaeva et al., 2000). Secondly, FDI generate positive spillovers

* Department of Economics and Statistics, University of Calabria, 87036, Campus di Arcavacata di Rende (Cosenza) - Italy (d.infante@unical.it). 
(Barba Navaretti and Venables, 2004) onto national companies by means of the indirect transfer of technologies and know-how which directly increase the technological level of the receiving country, thereby contributing to growth. Another advantage of FDI is that they can bridge the possible medium-term gap between domestic savings and investment needs (Campos and Coricelli, 2002) to accelerate the restructuring and modernization of transition economies. Some authors highlight the crowding effects of foreign investments. However, the results are not univocal (De Backer and Sleuwaegen, 2003). Mišun and Tomšík (2002) find that crowding effects are positive for some Central and Eastern European countries and negative for others, while Titarenko (2005) shows evidence of the negative long-term effect of FDI on investment in Latvia.

The flow of FDI into transition countries started in the 1990s. During the first years of transition, FDI stock increased dramatically, in some cases even by as much as 10 times. If in 1995 FDI stock in proportion to GDP was half the world average, by 2001 that stock had already reached the world level. In absolute terms the major recipients of FDI were Poland, Hungary, the Czech Republic and Russia, with a share around $70 \%$ of the total investments. However, smaller countries, such as the Czech Republic, Estonia and Croatia attracted higher investments in relative values than Russia.

Most foreign direct investments in transition countries come from the European Union, i.e. from neighbouring countries with whom they have very close historical and cultural ties. The second major investor for many countries is the United States. As far as sectoral distribution of FDI is concerned, the greater part of foreign market and efficient-seeking investments are directed towards the industrial sector. The foreign resource-seeking investments are directed mostly to Russia and other former members of the USSR, which are rich in natural resources. However, at the end of the 1990s, the direction of FDI gradually shifted from the industrial to the service sector and, within the services, from telecommunications, privatized during the transition, to business services.

The former socialist countries, each of which started from different levels of economic development and followed different transition paths, show highly diverse levels of FDI and despite the numerous empirical studies on FDI determinants, we still lack any univocal analysis of this phenomenon. This inhomogeneous distribution of FDI may point to the presence of specific market and institutional factors influencing the degree of attractiveness to investors, given that all of these countries in the move to market economy, experienced radical changes in their economies and institutions.

According to De Melo et al. (1997) the role played by the initial conditions and the macroeconomic policies is particularly relevant. Also decisive in determining levels of investment is the rate of reform. Among the transition countries, Pastore (2004) makes a distinction between the CEE countries, which witnessed a quicker and less traumatic reform, and the CIS countries, which underwent a longer and socially more difficult transition process. In fact, the frontrunner countries - such as the Czech Republic, Estonia, Hungary, Poland and Slovenia - succeeded in attracting a larger amount of FDI, whereas other countries with slower development, scarce entrepreneurial capacities (Infante and Smirnova, 2009a), and interruptions in the transition process 
due to a weak institutional environment, received less foreign investments (Castiglione et al., 2012).

For the present work, the institutional context is particularly important because the analysis is focused on the most intense period of transition and post-transition (19942002), a period characterized by the consequences of privatization, restructuring and re-organization of the economy and society.

In order to analyse the factors influencing the distribution of FDI, the economic literature identifies a series of potentially relevant variables for localizing of foreign direct investments. Some of these variables, such as market size, population, transport costs and distance are now considered as "classical" variables, whereas the importance of others, such as political and institutional variables, has been dealt with in special studies (Billington, 1999; Resmini, 1999; Altomonte, 2000; Smarzynska, 2002; Fabry and Zeghni, 2006).

In our empirical model, the choice of variables is based both on the determinants of FDI most commonly analysed in research and on variables which are crucial for identifying the direction and the amount of FDI within the weak institutional environment of economies undergoing transition. This paper differentiates itself from existing studies, therefore, by considering a richer set of possible FDI determinants; these range from specific market indicators, reflecting the workforce, openness, and agglomeration forces, to market creating and stabilising institutions, that influence FDI beyond those represented by the classical factors. The main objective of the work is to verify a) whether, in presence of additional variables, the classical factors maintain their significant role; b) the contribution of specific market variables; and c) the magnitude of the effects of market institutions on FDI.

This study is structured as follows. Section two analyses the classical, specific and institutional factors relevant to FDI attraction. Section three introduces the model and describes the nature of the data used. Section four gives the estimation results of different specifications of the model. Section five offers conclusions.

\section{The FDI Determinants}

There are two main theoretical strands that are commonly used to analyse the FDI phenomenon, and explain why firms use their affiliates to intervene in a foreign market rather than use export or licencing tools. On the one side, there is the so-called OLI approach based on Dunning $(1993,2001)$ theory according to which firms invest directly abroad to gain access to resources, markets, and make efficiency gains. On the other side, there is the gravitational approach that, despite its limited theoretical foundations (Oguledo and MacPhee, 1994), has proved to be an efficient tool for bilateral trade flow analysis, extended to foreign direct investments (Bergstrand, 1989; Resmini, 1999; Brenton, Di Mauro and Lücke, 1999; Altomonte, 2000; Cieślik and Ryan, 2004). Its application to foreign direct investments is implicit: if the countries 
are far from each other, then it is more convenient to produce abroad than to export, since the greater the distance the higher the transport costs.

In order to understand FDI determinants in transition countries we propose to go beyond the variables of the locational models and include specific aspects of market mechanisms, and market institutions. The variables used in the model are grouped and specified in Table 1.

\subsection{The Classical Factors}

Among the classical variables, market size, expressed both in absolute and in relative terms, is present in all studies dealing with FDI, and is specified in different ways (GDP, GDP per capita, and population). Smarzynska and Wei (2001) use GDP as proxy for the size of the market and per capita GDP as a measure of the consumer purchasing power, while Disdier and Meyer (2004) assume GDP as a proxy for the potential demand and GDP per capita as a measure of the level of development of the host country. Resmini (1999) adopts per capita GDP as a proxy for the current demand, and population for the absolute dimension of the market. Smarzynska (2002) and Altomonte (2000) interpret GDP per capita as local consumer purchasing power, and population as the local market potential. In our work two variables are considered as proxy of market size. One is the per capita GDP of country $i$ at time $t$, expressed in terms of purchasing power parity, at constant prices. The other variable, needed to grasp the gravitational force between countries, is the country's absolute size, expressed as the population of country $i$ at time $t$.

The distance between the country making the foreign investments and the recipient country is a necessary variable for the gravitational model. According to this model, the relationship between distance and FDI inflow can be both positive and negative. On the one hand, as distance increases, production costs abroad increase accordingly, because of greater cultural, linguistic, communicative and co-ordinating differences; on the other hand, with increasing distance FDI can become a trade substitute: the farther the countries are from each other, the higher the transport costs. At any rate, both positive and negative effects of distance can be important for an investor. In such cases, the sign of the distance coefficient is given by the prevailing effect. Most empirical studies find a negative relationship between the two variables (Brenton et al., 1999; Resmini, 1999; Bevan and Estrin, 2004; Disdier and Mayer, 2004).

Usually, the gravitational model requires FDI flow data from both the country that invest and the recipient country. When such information is not available, only the variables that characterize the receiving country are taken into consideration, while distance is measured from a fixed point (Resmini, 1999; Altomonte, 2000; Kinoshita and Campos, 2003). Our study uses this approach where foreign investments are related only to the recipient country, and distance is calculated as the distance from the capital of country $i$ from Brussels, since Brussels represents the centre of the European Union, which is often the major investor in transition countries. 


\subsection{Specific Factors}

One factor often taken into account in empirical studies of FDI is the workforce. In general, it is thought that foreign direct investments are attracted by countries with low labour costs or by the presence of significant differences between the cost of labour in the home country and in the recipient country (Altomonte, 2000; Bevan and Estrin, 2000; Kinoshita and Campos, 2003; Carstensen and Toubal, 2004; Disdier and Mayer, 2004). However, some studies do not find any significant correlation between FDI and the cost of labour (Garibaldi et al., 2001; Biswas, 2002; Kinoshita and Campos, 2003). In fact, foreign direct investments are attracted by low labour costs only in cases of efficiency-seeking FDI, targeted at specific developing countries. Thus, a negative sign is expected only for these economies. Conversely, in countries where FDI are of a resource-seeking or market seeking type we should not expect the labour cost variable to be relevant. Where a positive relationship between labour costs and foreign direct investments holds, other factors, such as level of education of the workforce, are taken into account (Wei, 1995; Carstensen and Toubal, 2004). On the basis of these finding we introduce two variables related to the workforce, such as the average monthly salary of the workers of country $i$ at time $t$, measured in real terms, and the quality of the work force measured as percentage of workforce with a secondary school diploma.

Any potential investor is directly interested in the way the country deals with capital inflow, for this defines the extent to which the transition country is open towards foreign countries, which also determines the level of restructuring and re-organization. Most empirical studies find a positive relationship between foreign direct investments and a country's openness, which can be expressed in different ways, using financial, commercial and tariff variables (Resmini, 1999; Kinoshita and Campos, 2003; Carstensen and Toubal, 2004). In our model we use variables such as the private capital inflow of country $i$ at time $t$ and the taxes from international trade as a percentage of the taxes collected overall.

Another factor, which potentially influences FDI, is the level of taxation on business. It is thought that a lower level of taxation corresponds to a higher inflow of FDI. Many empirical studies have confirmed this hypothesis (Smarzynska and Wei, 2001; Carstensen and Toubal, 2004; Bellak and Leibrecht, 2005). Thus we introduce the level of taxation on national corporations as a taxation indicator, expecting a negative relationship with FDI.

We choose four from the wide range of variables related to the industrial or development agglomeration used in empirical studies which explicitly indicate the country's level of development (Markusen and Venables, 1999; Co, 2000; De Backer and Sleuwaegen, 2003). The first one is a proxy variable for the technological development of the country and reflects the number of Internet users per 1000 people. A second variable indicates the development of high technology industries and is expressed as the percentage of exports of high technology products over total exports. The third one is the percentage of imports over the total imports of means of production and 
indicates the capacity of the country to invest in industrial development. Finally, since development is positively related to higher population density, we consider population density as workforce availability, which can also be a magnet for FDI.

The flow of FDI into transition countries is also influenced by other factors, specific to the economic context, that usually produce positive externalities on firms' productivity. Countries emerging from the socialist experience had to face the problem of the low quality and quantity of physical infrastructures. It has been shown (Kinoshita and Campos, 2003; Esfahani and Ramirez, 2003; Demirhan and Masca, 2008) that the quality and distribution of infrastructures positively influence both the productivity of national investments and the inflow of foreign direct investments.

Some authors use infrastructure proxies, such as the telephone network (Biswas, 2002; Kinoshita and Campos, 2003), capacity to generate electrical power (Biswas, 2002), public investment in the road network (Billington, 1999) and other indicators. We take into account three variables to represent both the quantity and the quality of infrastructures, namely the percentage of paved roads over the total of road network, the number of land lines and mobile phones per 100 inhabitants and the average cost of an overseas call.

\subsection{Institutional Factors}

Most economists today would argue that troubled transition processes are evident in countries which have overlooked the importance of establishing an institutional infrastructure based on legal, political, economical rules and organizations (Castiglione et al., 2012; Djankov et al., 2003; Fabry and Zeghni, 2006; Infante and Smirnova, 2010). A weak institutional environment often leads to market and state failures, allowing room for corruption, low-quality government and lacunae in the legal system. According to Infante and Smirnova (2009b) the institutional environment greatly affects the economic performance of firms, influencing their technological choices. Rodrik and Subramanian (2003) highlight the importance of institutions and distinguish different sets of institutions according to their function in economic development. In order to analyse the relationship between institutions and foreign direct investments we choose two of them: market creating institutions and market stabilizing institutions. 
Table 1

Explicative Variables

\begin{tabular}{|c|c|c|}
\hline Groups of variables & Variable & Definition \\
\hline \multicolumn{3}{|c|}{ Classical factors } \\
\hline \multirow[t]{2}{*}{ Market size } & $\mathrm{GDPPC}_{i \mathrm{t}}$ & $\begin{array}{l}\text { Per capita GDP of country } i \text { at time } t \text {, expressed in terms of } \\
\text { purchasing power parity, at constant prices }\end{array}$ \\
\hline & $P O P_{i t}$ & Population of country $i$ at time $t$ \\
\hline Distance & DIST $_{i}$ & Distance of the capital of country $i$ from Brussels \\
\hline \multicolumn{3}{|c|}{ Specific factors } \\
\hline \multirow[t]{2}{*}{ Workforce } & $W A G E_{i t}$ & $\begin{array}{l}\text { Average monthly salary of the workers of country } i \text { at time } t \text {, } \\
\text { measured in real terms }\end{array}$ \\
\hline & $2 E D_{i t}$ & Percentage of work force with a secondary education level \\
\hline \multirow[t]{3}{*}{ Openness of the economy } & $G P C A P F_{i t}$ & Gross inflow of private capital of the country $i$ at the time $t$ \\
\hline & TAXTRADE $E_{i t}$ & $\begin{array}{l}\text { Taxation on international trade as percentage of the total } \\
\text { amount of the collected taxes }\end{array}$ \\
\hline & $T A X C_{i t}$ & Highest rate of corporation tax at national level \\
\hline \multirow{4}{*}{$\begin{array}{l}\text { Industrial or development } \\
\text { agglomeration }\end{array}$} & INTERNET $T_{i t}$ & Number of Internet users per 1000 people \\
\hline & HITECH ${ }_{i t}$ & Percentage of high tech exports over total exportations \\
\hline & $M A N I M P_{i t}$ & $\begin{array}{l}\text { Percentage of means of production's imports over total } \\
\text { importations }\end{array}$ \\
\hline & POPDENS & Population density \\
\hline \multirow[t]{3}{*}{ Infrastructures } & $R O A D_{i t}$ & Percentage of paved roads over total roads \\
\hline & PHONE $_{i t}$ & Number of land lines and mobile phones per 1000 people \\
\hline & CALLUS $_{\text {it }}$ & Average cost of a phone call to the U.S. \\
\hline \multicolumn{3}{|c|}{ Institutional factors } \\
\hline \multirow[t]{5}{*}{ Market creating institutions } & EMPLLAW & Indicators of rigidity in employment laws \\
\hline & $\mathrm{CRRIGHT}_{\text {it }}$ & $\begin{array}{l}\text { Indicator of the extent to which existing legislation facilitates } \\
\text { the recovery of credit; the higher the value the greater the } \\
\text { chance of recovery }\end{array}$ \\
\hline & CONTRACT & $\begin{array}{l}\text { Indicator of difficulties in negotiating, expressed in number } \\
\text { of days to reach an agreement }\end{array}$ \\
\hline & STCOSTINC $_{i t}$ & $\begin{array}{l}\text { Business registration costs normalized to per capita gross } \\
\text { national income }\end{array}$ \\
\hline & PRIV & $\begin{array}{l}\text { Indicator on a scale of } 1 \text { to } 4 \text {, where } 4 \text { represents the } \\
\text { highest chance for foreign investors to participate in } \\
\text { privatization }\end{array}$ \\
\hline \multirow[t]{3}{*}{ Market stabilizing institutions } & $I N F_{i t}$ & Annual inflation rate \\
\hline & $R E X C H R_{i t}$ & Real exchange rate \\
\hline & $U N E M P L_{i t}$ & Unemployment rate \\
\hline \multicolumn{3}{|c|}{ Qualitative factors } \\
\hline \multirow[t]{3}{*}{ Binary variable } & $D^{D} U R \cup S_{i t}$ & Value 1 for Russia and 0 for other countries \\
\hline & $D U M C I S_{i t}$ & $\begin{array}{l}\text { Value } 1 \text { for former members of USSR countries (Baltic } \\
\text { countries excluded) and } 0 \text { for other countries }\end{array}$ \\
\hline & DUMEU $U_{i t}$ & $\begin{array}{l}\text { Value } 1 \text { for the transition countries that recently joined the } \\
\text { EU, value } 0 \text { for other countries }\end{array}$ \\
\hline
\end{tabular}


The set of market creating institutions is closely linked to the country's legal system and is seen as a proxy for market institutions or business environment. Smarzynska (2002) has included in her analysis the variable of legal system efficiency as an indicator of the extent to which the investment legislation is clear and adequately supported by juridical and administrative rules. According to Smarzynska, the relationship between the efficiency of the legal system and FDI is positive. This finding is confirmed by Kinoshita and Campos (2003), and Globerman and Shapiro (2002). Next to the legal system there are other equally important factors for the business environment, such as ease of business registration and negotiation in general, various aspects of which have been examined by Garibaldi et al. (2001). Among the market creating institutions four variables are taken into account in our work. The first is an indicator of rigidity in employment laws. We assume that low rigidity in employment legislation constitutes an incentive for foreign investors. Another variable is an indicator that shows the extent to which existing legislation facilitates the receipt of credit. The third one is an indicator of the cost of business registration, normalized to per capita gross national income. This is a measure of the presence of obstacles when undertaking doing business which should be negatively related to foreign investments. Finally, we introduce the indicator of the presence of difficulties in negotiation in general, expressed by the number of days required to reach an agreement.

Massive privatization is a typical process in countries whose aim is the construction of market creating institutions such as private firms. However, the process of privatisation has proved to be very tortuous and has often lead to the concentration of power, creating obstacles to FDI, and failing to achieve the goal of economic freedom. Some studies consider both the volume of privatization (Holland and Pain, 1998 and Smarzynska, 2002) and the privatization procedure (Garibaldi et al., 2001; Carstensen and Toubal, 2004) on FDI, while others (Galeotti and Ryšavá, 2008) consider the numbers of years from privatization as determinant for foreign investment. In our model we try to capture the effects of privatisation by using the Holland and Pain's (1998) method.

Market stabilizing institutions are also crucial in evaluating whether to invest in transition countries. One of the proxies used for quality of institutions is economic stability represented by macroeconomic indicators. Garibaldi et al. (2001), Kinoshita and Campos (2003) find a negative relationship between the inflation rate and FDI. Disdier and Mayer (2004), on the other hand, use exchange rate the instability as a proxy for economic stability, finding it negatively related to foreign direct investments. Garibaldi et al. (2001) have also shown that a stable exchange rate positively influences foreign investments. Other authors (Boeri and Terrell 2002, and Disdier and Mayer 2004) have taken into account a real variable, such as the unemployment rate, to show that availability of a workforce is a positive sign for foreign investors. In our study we take into account the annual inflation rate, the real exchange rate and the unemployment rate in verifying the effects of the market stabilising institutions on investments. 


\subsection{Qualitative Factors}

Finally, we also verify the factors which attract FDI in national contexts, by introducing binary variables. The first dummy allows us to analyse if, ceteris paribus, there are country specific effects which attract FDI in Russia, the largest country involved in the transition process. The second takes into account the country's affiliation to the former-USSR (with the exception of the Baltic states). The last dummy involves those countries that have recently joined the European Union, which is the major investor in the transition countries. Indeed, European Union membership sends a strong signal to a potential investor, being a sort of guarantee of political and economic stability (Kimberly and Cosmina, 2005).

\section{Model and Data Specification}

The specification of the model we estimate in the present work, is a three classical variables model augmented by additional specific explicative variables that represent the effects influencing the volume of FDI inflows beyond those represented by market size and distance. It takes the following form:

$$
\ln \text { FIDIST }_{i t}=\alpha_{0}+\alpha_{1} \ln \text { DDPPC }_{i t}+\alpha_{2} \ln P O P_{i t}+\alpha_{3} \ln D I S T_{i}+\sum_{j=4}^{n} \alpha_{j} x_{j i t}+\varepsilon_{i t}
$$

where: FIDIST $_{i t}$ is the stock of FDI in country $i$ at time $t$;

$G D P P C_{i t}$ is the per capita GDP of country $i$ at time $t$;

$P O P_{i t} \quad$ is the population of country $i$ at time $t$;

$D I S T_{i} \quad$ is the distance of country $i$ 's capital from Brussels;

$x_{j i t} \quad$ are other transition countries specific and institutional variables which might influence the volume of foreign direct investment.

The panel data used for the analysis covers 26 transition countries ${ }^{1}$ for the years 1994-2002. The main sources of the data are the World Bank Development Indicators, 2004 Edition; the data on FDI stock are taken from the UNCTAD World Investment Report, whereas the data on wages are taken from the LABORSTA database of the International Labour Office (ILO). By pooling the data of 26 countries we introduce more heterogeneity, on the assumption that countries that attract market or efficiencyseeking FDI may have different FDI functions than countries that attract resourceseeking FDI. However, this heterogeneity can be an advantage for the present econometric model that aims to incorporate different FDI determinants.

1 The 26 transition countries included in the sample are the following: the Czech Republic, Hungary, Poland, the Slovak Republic, Slovenia, Estonia, Latvia, Lithuania, Albania, Bosnia and Herzegovina, Bulgaria, Croatia, FYR Macedonia, Romania, Serbia and Montenegro, Russia, Ukraine, Belarus, Moldova, Armenia, Azerbaijan, Georgia, Kazakhstan, Kyrgyzstan, Tajikistan, Turkmenistan and Uzbekistan. 
The data used in our estimations present two kinds of problems. First of all, because of its incompleteness the panel data is unbalanced (it lacks single observations for some countries and periods). Secondly, some series of the data are closely related to each other, leading to problems of multicollinearity. In order to obviate these problems we add one explicative variable at a time when estimating the basic model. This allows us to establish the FDI determinants for the transition countries using the most extensive series of data possible, lowering the possible bias due to omitted variables. Finally, the whole model including the most part of the explicative variables is introduced.

\section{Model Estimation Results}

The results of the OLS estimation (not reported) showed that few specifications suffer from heteroschedasticity, as results from the White test indicate. The presence of heteroschedasticity can be explained by the heterogeneity of the sample countries - in fact, the countries investigated differ dramatically in size, income, and other variables. The major problem is represented by autocorrelation, explained by the inertia of some of the variables. In order to avoid such problems we used the FGLS estimation with Prais-Winsten transformation (Table 2).

Another problem we face is endogeneity. In order to solve this, we apply the instrumental variables method (Table 3), testing endogeneity by means of the DurbinWu-Hausman $\chi^{2}$ test (results not reported). Given that, for the best estimation properties using the GMM method, a wide sample of data is required (Cheng and Kwan, 2000; Kinoshita and Campos, 2003), we opted for the 2SLS estimation, despite the presence of heteroschedasticity. ${ }^{2}$

The results obtained in the Prais-Winsten and 2SLS estimations confirm our main hypothesis. Both in absolute (population) and in relative terms (per capita GDP) market size is positively related to foreign direct investments. Both variables are statistically significant in all the specifications of the model. The distance variable of the transition countries from the EU "economic centre" shows a positive sign in eight out of nine estimations. Despite oscillations in the significance of the distance variable, the greater the distance from Brussels, ceteris paribus, the more FDI stock grows. This confirms that, given the greater distance, foreign direct investments tend to substitute trade. Consequently, the effect of distance on FDI is positive and the majority of investments in the transition countries can be considered to be of a marketseeking or resource-seeking type.

2 Given that in presence of heteroschedasticity the GMM estimation is to be preferred to the 2SLS (Baum, Schaffer and Stillman 2003), the GMM estimations have been calculated and compared to the 2SLS. However, the results are not reported as they are almost identical. 
Table 2

FDI determinants in transition countries: Prais-Winsten estimation (1994-2002), dependent variable: $\log (\mathrm{FDIST})$

\begin{tabular}{|c|c|c|c|c|c|c|c|c|c|c|c|c|c|}
\hline \multirow{2}{*}{$\begin{array}{c}\text { Variables } \\
\text { C }\end{array}$} & \multirow{2}{*}{\begin{tabular}{c|}
$\begin{array}{c}\text { Classical } \\
\text { variables }\end{array}$ \\
$-13.937^{\star \star}$ \\
$(-1.98)$
\end{tabular}} & \multicolumn{2}{|c|}{ Workforce } & \multicolumn{2}{|c|}{ Openess } & \multicolumn{2}{|c|}{$\begin{array}{l}\text { Concentration } \\
\text { of development }\end{array}$} & \multirow{2}{*}{$\begin{array}{c}\begin{array}{c}\text { Infrastruc- } \\
\text { tures }\end{array} \\
-9.633^{* \star} \\
(-2.30)\end{array}$} & \multirow{2}{*}{ 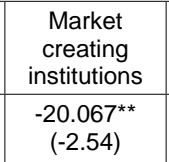 } & \multicolumn{3}{|c|}{ Market stabilising institutions } & \multirow{2}{*}{$\begin{array}{c}\text { Dummies } \\
-16.667^{\star \star \star} \\
(-2.31)\end{array}$} \\
\hline & & $\begin{array}{c}-14.142^{\star \star} \\
(-2.11)\end{array}$ & $\begin{array}{c}-19.093 \\
(-2.21)\end{array}$ & $\begin{array}{c}-29.947^{* * *} \\
(-2.69)\end{array}$ & $\begin{array}{l}-19.556 \\
(-1.32)\end{array}$ & $\begin{array}{l}-4.068 \\
(-1.01)\end{array}$ & $\begin{array}{c}-28.229^{* * *} \\
(-2.87)\end{array}$ & & & $\begin{array}{c}-10.583^{* *} \\
(-2.12)\end{array}$ & $\begin{array}{c}22.883^{* *} \\
(-1.99)\end{array}$ & $\begin{array}{c}-11.408 \\
(-1.53)\end{array}$ & \\
\hline LOG(GDPPC) & $\begin{array}{c}2.078^{* * *} \\
(5.47)\end{array}$ & $\begin{array}{l}0.444 \\
(0.87) \\
\end{array}$ & $\begin{array}{l}1.955^{\star *} \\
(2.35)\end{array}$ & $\begin{array}{c}2.859^{* * *} \\
(5.22)\end{array}$ & $\begin{array}{l}2.199 * * \\
(2.03)\end{array}$ & $\begin{array}{l}0.449^{\star *} \\
(2.33)\end{array}$ & $\begin{array}{c}2.640^{\star \star \star} \\
(5.90)\end{array}$ & $\begin{array}{c}1.075^{\star \star \star} \\
(4.11)\end{array}$ & $\begin{array}{c}2.526^{* * *} \\
(5.78)\end{array}$ & $\begin{array}{c}1.503^{* * *} \\
(5.26)\end{array}$ & $\begin{array}{c}1.696^{\star \star \star} \\
(2.95)\end{array}$ & $\begin{array}{c}2.040^{* * *} \\
(5.49)\end{array}$ & $\begin{array}{c}1.875^{\star * \star} \\
(4.32)\end{array}$ \\
\hline LOG(POP) & $\begin{array}{c}0.831^{\star \star *} \\
(5.90)\end{array}$ & $\begin{array}{c}1.043^{* \star *} \\
(6.70)\end{array}$ & $\begin{array}{c}0.783^{\star \star *} \\
(6.42)\end{array}$ & $\begin{array}{c}0.721^{* \star *} \\
(2.64)\end{array}$ & $\begin{array}{c}0.955^{\star \star \star} \\
(6.96)\end{array}$ & $\begin{array}{c}0.903^{\star \star *} \\
(17.20)\end{array}$ & $\begin{array}{c}0.790^{* \star *} \\
(5.93) \\
\end{array}$ & $\begin{array}{c}0.861^{* * *} \\
(9.89)\end{array}$ & $\begin{array}{c}0.805^{\star \star \star} \\
(5.25)\end{array}$ & $\begin{array}{c}1.080^{\star \star *} \\
(8.98)\end{array}$ & $\begin{array}{c}0.792^{* * \star} \\
(3.39)\end{array}$ & $\begin{array}{c}0.723^{\star \star \star} \\
(6.40)\end{array}$ & $\begin{array}{c}1.000^{* \star *} \\
(6.08)\end{array}$ \\
\hline LOG(DIST) & $\begin{array}{l}0.527 \\
(0.90) \\
\end{array}$ & $\begin{array}{l}0.875 \\
(1.64) \\
\end{array}$ & $\begin{array}{l}0.956 \\
(1.13) \\
\end{array}$ & $\begin{array}{l}1.789^{*} \\
(1.91)\end{array}$ & $\begin{array}{l}1.064^{*} \\
(1.76) \\
\end{array}$ & $\begin{array}{l}0.531 \\
(1.42) \\
\end{array}$ & $\begin{array}{c}1.735^{\star *} \\
(2.05)\end{array}$ & $\begin{array}{c}0.985^{\star \star \star} \\
(2.92) \\
\end{array}$ & $\begin{array}{c}1.235^{\star *} \\
(2.14) \\
\end{array}$ & $\begin{array}{l}0.437 \\
(1.02) \\
\end{array}$ & $\begin{array}{l}-0.274 \\
(-0.27) \\
\end{array}$ & $\begin{array}{l}0.478 \\
(0.79) \\
\end{array}$ & $\begin{array}{l}0.726 \\
(1.23) \\
\end{array}$ \\
\hline & & $\begin{array}{c}\text { LOG } \\
\text { (WAGE) }\end{array}$ & $\begin{array}{c}\text { LOG } \\
\text { (WAGE) }\end{array}$ & $\begin{array}{c}\mathrm{LOG} \\
\text { (GPCAPF) }\end{array}$ & TAXC & $\begin{array}{c}\text { LOG } \\
(\mathrm{HITECH})\end{array}$ & POPDENS & PHONE & $\begin{array}{c}\text { LOG } \\
\text { (EMPLLAW) }\end{array}$ & LOG(INF) & $\begin{array}{c}\text { LOG } \\
\text { (REXCHR) }\end{array}$ & UNEMP & DUMRUS \\
\hline & & $\begin{array}{c}1.648^{* * *} \\
(4.28)\end{array}$ & $\begin{array}{l}0.640^{*} \\
(1.71)\end{array}$ & $\begin{array}{c}0.636^{* * *} \\
(3.19)\end{array}$ & $\begin{array}{l}-0.022^{*} \\
(-1.76) \\
\end{array}$ & $\begin{array}{l}0.079 \\
(1.00)\end{array}$ & $\begin{array}{l}0.014^{* *} \\
(2.07)\end{array}$ & $\begin{array}{l}0.001^{* *} \\
(2.58)\end{array}$ & $\begin{array}{l}-1.067 \\
(-1.08) \\
\end{array}$ & $\begin{array}{c}-0.603^{* * *} \\
(-6.28)\end{array}$ & $\begin{array}{c}4.022^{* \star *} \\
(7.30)\end{array}$ & $\begin{array}{l}-0.015 \\
(-0.43) \\
\end{array}$ & $\begin{array}{l}-1.004^{* *} \\
(-1.55)\end{array}$ \\
\hline & & & 2ED & & TAXTRADE & $\begin{array}{c}\text { LOG } \\
\text { (INTERNET) }\end{array}$ & & $\begin{array}{c}\text { LOG } \\
\text { (CALLUS) }\end{array}$ & $\begin{array}{c}\text { LOG } \\
\text { (STCOSTINC) }\end{array}$ & & & & DUMEU \\
\hline & & & $\begin{array}{l}0.007 \\
(0.93) \\
\end{array}$ & & $\begin{array}{c}-0.133^{\star \star *} \\
(-5.71)\end{array}$ & $\begin{array}{c}0.358^{* * *} \\
(4.62)\end{array}$ & & $\begin{array}{c}-0.266^{\star * *} \\
(-2.70)\end{array}$ & $\begin{array}{c}0.627^{* \star *} \\
(2.74)\end{array}$ & & & & $\begin{array}{l}0.852 \\
(1.36) \\
\end{array}$ \\
\hline & & & DUMEU & & & MANIMP & & ROADD & & & & & \\
\hline & & & $\begin{array}{l}0.276 \\
(0.80) \\
\end{array}$ & & & $\begin{array}{l}0.036^{* \star *} \\
(4.10)\end{array}$ & & $\begin{array}{c}1.279^{* * *} \\
(5.73) \\
\end{array}$ & & & & & \\
\hline Adjusted $\mathrm{R}^{2}$ & 0.611 & 0.769 & 0.984 & 0.843 & 0.923 & 0.913 & 0.605 & 0.995 & 0.668 & 0.803 & 0.795 & 0.758 & 0.601 \\
\hline $\begin{array}{c}\text { F-statistic } \\
\text { Prob }\end{array}$ & \begin{tabular}{|c|}
4740.08 \\
0.000 \\
\end{tabular} & \begin{tabular}{|c|}
3707.83 \\
0.000 \\
\end{tabular} & $\begin{array}{c}3202.20 \\
0.000\end{array}$ & $\begin{array}{l}781.77 \\
0.000 \\
\end{array}$ & $\begin{array}{c}4686.01 \\
0.000\end{array}$ & $\begin{array}{c}22593.49 \\
0.000 \\
\end{array}$ & $\begin{array}{c}4969.49 \\
0.000\end{array}$ & $\begin{array}{c}13402.40 \\
0.000\end{array}$ & $\begin{array}{c}3837.33 \\
0.000\end{array}$ & $\begin{array}{c}9437.79 \\
0.000 \\
\end{array}$ & $\begin{array}{c}5614.43 \\
0.000 \\
\end{array}$ & $\begin{array}{c}3502.97 \\
0.000\end{array}$ & $\begin{array}{l}4822.47 \\
0.000\end{array}$ \\
\hline $\begin{array}{c}\text { Durbin-Watson } \\
\text { test }\end{array}$ & 1.341 & 1.545 & 0.831 & 2.258 & 1.639 & 1.345 & 1.340 & 0.533 & 1.380 & 1.645 & 1.355 & 1.279 & 1.317 \\
\hline $\begin{array}{c}\text { Hausman test } \\
\text { Prob. }\end{array}$ & -0.44 & -3.78 & $\begin{array}{l}6.00 \\
0.423\end{array}$ & $\begin{array}{c}2760.20 \\
0.000\end{array}$ & $\begin{array}{c}100.34 \\
0.000\end{array}$ & $\begin{array}{c}1.88 \\
0.931\end{array}$ & -0.46 & -3.82 & -0.73 & -2.25 & $\begin{array}{c}0.52 \\
0.972\end{array}$ & -1.30 & -0.47 \\
\hline n. obs. & 224 & 180 & 72 & 192 & 106 & 158 & 221 & 104 & 189 & 218 & 113 & 175 & 224 \\
\hline
\end{tabular}

- The t-Student values are reported in brackets.

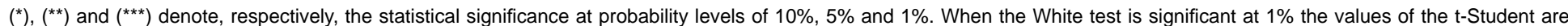
calculated using the matrix of standard errors and the co-variances with the correction of White for heteroschedasticity.

The values of Durbin-Watson statistics are reported in the transformed estimation. 


\section{$\vec{P} \quad$ Table 3}

FDI determinants in transition countries: 2SLS estimation (1995-2002), dependent variable: log(FDIST)

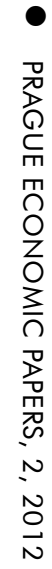

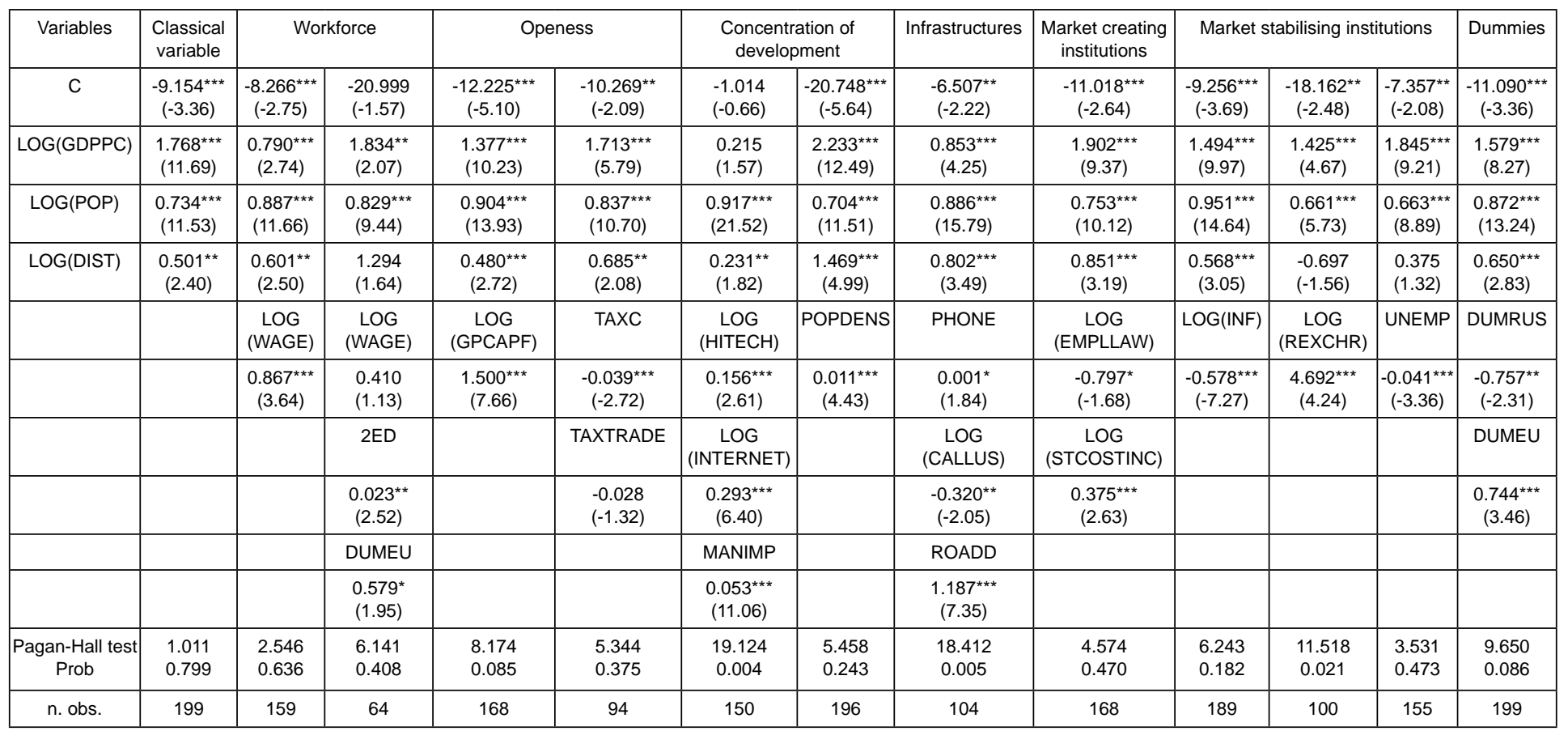

The t-Student values are reported in brackets.

$\left({ }^{*}\right),\left(^{* *}\right)$ and $\left(^{* \star *}\right)$ denote, respectively, the statistical significance at probability levels of $10 \%, 5 \%$ and $1 \%$.

* the values of $\mathrm{t}$-Student are calculated using the Eicker-Huber-White "sandwich" matrix for heteroschedasticity correction. 
The labour cost variable is highly significant and positive, whereas its expected sign is negative. This is due to the different types of investment directed to different countries. The most developed Central and Eastern European countries are known to receive market-seeking and, to a lesser extent, efficiency-seeking investments, whereas the former USSR countries receive resource-seeking and market-seeking investments. It is also true that potential investors take into consideration not just the cost but also the quality of labour. Wage differences between the countries can be also ascribed to differences in the quality of the workforce. The application of a dummy for the "wealthier" countries - DUMEU - and the variable of labour education 2ED, confirm that the most developed of the transition countries, those with better educated workforce and higher wages in comparison to other transition countries, attract more investments, ceteris paribus. The introduction of a dummy for EU candidate countries, absorbs part of the role played by high wages, reinforcing the findings that candidate countries attract more FDI even if their workforce enjoy higher wages.

Regarding the variables on market openness, the GPCAPF variable, which measures openness towards foreign countries expressed in terms of private capital inflows, has a positive sign and is statistically significant in all estimations. The TAXTRADE variable, which represents the trade barrier level, is also statistically significant (except for the 2SLS estimation) with the expected negative sign. Differences in tariff policy rates are probably not so important for foreign investors. In this case the trade barrier may act as a signal to the investor of the country's relative reluctance to co-operate with foreign countries. TAXTRADE can, therefore, be complementary to GPCAPF. The variable that characterizes the business climate of the country, TAXC, carries a negative sign and is statistically significant in all estimations, confirming that foreign investors take into consideration the tax level on profits and invest in countries with lower taxation levels.

The high significance of the variables regarding industrial and technological development (HITECH, INTERNET and MANIMP) shows that foreign investors are mainly directed to countries that have already achieved a level of development that allows them to exploit pre-existing industrial establishments. The presence of high technology industries in the receiving countries indicates the existence of a highly qualified workforce, another important element for foreign investors. Density of population, expressed by the POPDENS variable, also registers a positive sign, and the high significance obtained in all estimations confirms the hypothesis that the agglomeration of population is one of the factors which attract FDI, even though the magnitude of the coefficient is not very high.

The importance of infrastructures for FDI is shown by the significance of the infrastructure variables: the number of land lines and mobile phone owners PHONE, the percentage of paved roads over the total of roads ROAD, and the cost of a phone call to the United States CALLUS. In particular, the magnitude of the parameter of ROAD shows that an increase of $1 \%$ in paved roads leads to an increase of $1.2 \%$ of FDI. 
As far as the variables characterizing market creating institutions are concerned, the parameter regarding the employment in the legislation variable (EMPLLAW) carries the expected sign: extreme rigidity laws has a negative influence on FDI. However, the parameter relating to the business registration cost variable (STCOSTINC) carries an unexpected positive sign. It could be that the business registration cost is not important for investors, because many of them would not be starting a new activity, or because registration cost is not significant when compared to the size of the investment. Other variables (not reported in the tables), such as the business environment (CONTRACT and CRRIGHT) and privatisation (PRIV) are not significant for undertaking investment.

On the other side, the role of the variables representing market stabilizing institutions (INF, REXCHR and UNEMPL) is significant. The inflation variable carries a negative sign and is highly significant in all estimations. A $1 \%$ increase in inflation leads to a $0.6 \%$ decrease in FDI stock, confirming that high inflation rates indicate an unstable macroeconomic context which in turn increases business costs. The variable related to the real exchange rate, REXCHR, used as a proxy for economic stability, shows a positive sign and very high significance with a high elasticity value. The other variable related to market stabilising institutions, regarding unemployment, UNEMPL, carries a negative sign and it is significant only in the 2SLS estimation. This result allows us to conclude that for our sample countries the variable indicates the state of reforms: a high unemployment rate is a sign of economic and social reforms still in progress, and of an economy which has not yet recovered from the transition process.

The effects registered by the dummy variable, DUMRUS, show that, ceteris paribus, investors refrain from investing in Russia, while they prefer to invest in new EU members. Yet, Russia is often thought of as an economically appealing country by foreign investors even though it is potentially unstable due to the persistent failure to establish the rule of law. In fact, some studies confirm that FDI were not decisive for Russian economic growth during transition period (Ledyaeva and Linden, 2008). Conversely, candidacy for admission to the EU can be regarded as a sign of a country's progress in making reforms and achieving political and economic stability. From our estimations we notice that the increase in FDI stock due to the announcement of forthcoming EU membership is $130 \%$ higher in comparison with that of the other transition countries.

Table 4 reports the estimation of a model which includes the highest possible number of variables and binary variables. As we can see, the significance and the sign of the main variables are unaltered. Both variables related to market size carry a positive sign and are highly significant. The distance variable is $10 \%$ significant in the 2 SLS estimation, whereas it is not significant in the FGLS estimation. The variables of the trade barrier, of openness towards foreign countries and of the institutional context (GPCAPF, MANIMP and UNEMP) are significant and carry the same sign, confirming previously reported results. 
Table 4

FDI determinants in transition countries: the complete model (1995-2002), dependent variable: $\log ($ FDIST)

\begin{tabular}{|c|c|c|}
\hline Variables & Prais-Winsten & $2 S L S$ \\
\hline C & $\begin{array}{l}-6.564^{*} \\
(-1.79)\end{array}$ & $\begin{array}{l}-6.658^{\star *} \\
(-2.29)\end{array}$ \\
\hline LOG(GDPPC) & $\begin{array}{c}0.849^{* * *} \\
(2.63)\end{array}$ & $\begin{array}{c}0.755^{\star \star \star} \\
(2.69)\end{array}$ \\
\hline LOG(POP) & $\begin{array}{l}1.016^{\star * *} \\
(15.99)\end{array}$ & $\begin{array}{c}1.040^{\star * *} \\
(21.62)\end{array}$ \\
\hline LOG(DIST) & $\begin{array}{l}0.328 \\
(1.28)\end{array}$ & $\begin{array}{l}0.352^{*} \\
(1.79)\end{array}$ \\
\hline TAXC & $\begin{array}{c}-0.034^{* * *} \\
(-3.71)\end{array}$ & $\begin{array}{c}-0.036^{* *} \\
(-4.77)\end{array}$ \\
\hline LOG(GPCAPF) & $\begin{array}{c}0.279^{\star * \star *} \\
(2.84)\end{array}$ & $\begin{array}{c}0.344^{\star \star *} \\
(3.05)\end{array}$ \\
\hline MANIMP & $\begin{array}{c}0.047^{* * *} \\
(6.54)\end{array}$ & $\begin{array}{c}0.050^{* * *} \\
(8.22)\end{array}$ \\
\hline PHONE & $\begin{array}{l}0.0004 \\
(0.99)\end{array}$ & $\begin{array}{l}0.001^{*} \\
(1.69)\end{array}$ \\
\hline LOG(INF) & $\begin{array}{l}-0.047 \\
(-0.91)\end{array}$ & $\begin{array}{c}-0.109^{*} \\
(-1.95)\end{array}$ \\
\hline LOG(WAGE) & $\begin{array}{l}-0.255 \\
(-1.27)\end{array}$ & $\begin{array}{l}-0.196 \\
(-1.09)\end{array}$ \\
\hline UNEMP & $\begin{array}{l}-0.026^{*} \\
(-1.92)\end{array}$ & $\begin{array}{c}-0.025^{\star \star} \\
(-2.22)\end{array}$ \\
\hline DUMEU & $\begin{array}{l}0.657^{* *} \\
(2.45)\end{array}$ & $\begin{array}{c}0.453^{\star *} \\
(2.10)\end{array}$ \\
\hline DUM96 & $\begin{array}{l}0.172 \\
(1.52)\end{array}$ & $\begin{array}{l}0.183 \\
(1.18)\end{array}$ \\
\hline DUM97 & $\begin{array}{c}0.588^{* * *} \\
(4.22)\end{array}$ & $\begin{array}{c}0.527^{* * *} \\
(3.23)\end{array}$ \\
\hline DUM98 & $\begin{array}{c}0.728^{* * *} \\
(4.36)\end{array}$ & $\begin{array}{c}0.592^{* * *} \\
(3.30)\end{array}$ \\
\hline DUM99 & $\begin{array}{c}0.768^{\star \star \star} \\
(3.97)\end{array}$ & $\begin{array}{c}0.605^{\star \star \star} \\
(3.02)\end{array}$ \\
\hline DUM2000 & $\begin{array}{c}0.875^{* * *} \\
(4.09)\end{array}$ & $\begin{array}{c}0.729^{* * *} \\
(3.31)\end{array}$ \\
\hline DUM2001 & $\begin{array}{c}0.737^{\star * *} \\
(2.86)\end{array}$ & $\begin{array}{l}0.527^{*} \\
(1.98)\end{array}$ \\
\hline DUM2002 & $\begin{array}{c}1.052^{\star \star \star *} \\
(3.10)\end{array}$ & $\begin{array}{c}0.725^{* *} \\
(2.01)\end{array}$ \\
\hline Adjusted $\mathbf{R}^{2}$ & 0.987 & \\
\hline $\begin{array}{l}\text { F-statistic } \\
\text { Prob }\end{array}$ & $\begin{array}{c}399.30 \\
0.000\end{array}$ & \\
\hline $\begin{array}{l}\text { White test/Pagan-Hall } \\
\text { Prob. }\end{array}$ & & $\begin{array}{l}21.071 \\
0.276\end{array}$ \\
\hline Durbin-Watson test & 1.046 & \\
\hline \multicolumn{3}{|l|}{$\begin{array}{l}\text { Reset test } \\
\text { Prob. }\end{array}$} \\
\hline $\begin{array}{l}\text { Hausman test } \\
\text { Prob. }\end{array}$ & $\begin{array}{l}8.91 \\
0.962\end{array}$ & $\begin{array}{l}0.84 \\
0.361\end{array}$ \\
\hline n. obs & 93 & 93 \\
\hline
\end{tabular}

The t-Student values are given in brackets, and are calculated using the matrix of standard errors and the co-variances with White's correction for heteroschedasticity.

$\left({ }^{\star}\right),\left({ }^{* \star}\right)$ and $\left({ }^{* \star *}\right)$ denote, respectively, the statistical significance at the probability level of $10 \%, 5 \%$ and $1 \%$. 
Table 5

FDI determinants in transition countries: fixed effects estimation. 1995-2002, dependent variable: $\log$ (FDIST)

\begin{tabular}{|c|c|c|}
\hline Variables & Prais-Winsten & 2SLS \\
\hline LOG(GDPPC) & $\begin{array}{c}1.707^{* \star *} \\
(2.99)\end{array}$ & $\begin{array}{c}1.473^{\star *} \\
(2.48)\end{array}$ \\
\hline LOG(POP) & $\begin{array}{l}0.700 \\
(0.25)\end{array}$ & $\begin{array}{l}1.186 \\
(0.49)\end{array}$ \\
\hline LOG(DIST) & $\begin{array}{l}-0.626 \\
(-0.12)\end{array}$ & $\begin{array}{l}-1.464 \\
(-0.33)\end{array}$ \\
\hline LOG(WAGE) & $\begin{array}{l}-0.274 \\
(-1.06)\end{array}$ & $\begin{array}{l}-0.097 \\
(-0.26)\end{array}$ \\
\hline LOG(GPCAPF) & $\begin{array}{c}0.239^{* *} \\
(2.25)\end{array}$ & $\begin{array}{c}0.298^{\star * *} \\
(2.91)\end{array}$ \\
\hline MANIMP & $\begin{array}{c}0.056^{* * *} \\
(6.32)\end{array}$ & $\begin{array}{c}0.062^{\text {***}} \\
(7.64)\end{array}$ \\
\hline PHONE & $\begin{array}{c}0.001^{* \star *} \\
(2.73)\end{array}$ & $\begin{array}{c}0.001^{* * \star} \\
(3.14)\end{array}$ \\
\hline LOG(INF) & $\begin{array}{c}-0.108^{\star *} \\
(-2.27)\end{array}$ & $\begin{array}{c}-0.090^{*} \\
(-1.89)\end{array}$ \\
\hline TAXC & $\begin{array}{c}-0.030^{\star *} \\
(-2.31)\end{array}$ & $\begin{array}{c}-0.025^{\star \star} \\
(-2.31)\end{array}$ \\
\hline Armenia & $\begin{array}{l}-0.624 \\
(-0.47)\end{array}$ & $\begin{array}{l}-0.544 \\
(-0.45)\end{array}$ \\
\hline Azerbaijan & $\begin{array}{l}0.315 \\
(0.09)\end{array}$ & $\begin{array}{l}-0.237 \\
(-0.07)\end{array}$ \\
\hline Bulgaria & $\begin{array}{l}-1.777 \\
(-0.24)\end{array}$ & $\begin{array}{l}-2.723 \\
(-0.42)\end{array}$ \\
\hline Czech Repubblic & $\begin{array}{l}-2.767 \\
(-0.22) \\
\end{array}$ & $\begin{array}{l}-4.784 \\
(-0.44)\end{array}$ \\
\hline Estonia & $\begin{array}{l}-2.125 \\
(-0.69)\end{array}$ & $\begin{array}{l}-2.496 \\
(-0.93)\end{array}$ \\
\hline Kazhakstan & $\begin{array}{l}-0.209 \\
(-0.06)\end{array}$ & $\begin{array}{l}-0.701 \\
(-0.25)\end{array}$ \\
\hline Latvia & $\begin{array}{l}-2.248 \\
(-0.46)\end{array}$ & $\begin{array}{l}-2.918 \\
(-0.69)\end{array}$ \\
\hline Lithuania & $\begin{array}{l}-2.401 \\
(-0.40)\end{array}$ & $\begin{array}{l}-3.397 \\
(-0.66)\end{array}$ \\
\hline Poland & $\begin{array}{l}-1.701 \\
(-0.12)\end{array}$ & $\begin{array}{l}-4.002 \\
(-0.34)\end{array}$ \\
\hline Romania & $\begin{array}{l}-1.774 \\
(-0.18) \\
\end{array}$ & $\begin{array}{l}-3.328 \\
(-0.39)\end{array}$ \\
\hline Russia & $\begin{array}{l}-0.657 \\
(-0.05)\end{array}$ & $\begin{array}{l}-2.746 \\
(-0.23)\end{array}$ \\
\hline
\end{tabular}




\begin{tabular}{|l|c|c|}
\hline Variables & Prais-Winsten & 2SLS \\
\hline Slovak Republic & -3.054 & -4.468 \\
& $(-0.33)$ & $(-0.56)$ \\
\hline Ucraina & -0.749 & -2.443 \\
& $(-0.06)$ & $(-0.24)$ \\
\hline Hungary & -2.253 & -3.854 \\
& $(-0.22)$ & $(-0.44)$ \\
\hline Slovenia & -3.412 & -4.423 \\
& $(-0.50)$ & $(-0.75)$ \\
\hline Adjusted R & 0.9996 & \\
\hline F-statistic & 10856.10 & \\
Prob & 0.000 & 33.899 \\
\hline White test/Pagan-Hall & & 0.087 \\
Prob. & & \\
\hline Durbin-Watson test & 1.285 & -31.11 \\
\hline Hausman test & -2.66 & 106 \\
\hline n. obs & 106 & \\
\hline
\end{tabular}

The t-Student values are reported in brackets.

$\left({ }^{*}\right),\left({ }^{* *}\right)$ and $\left(^{* * *}\right)$ denote, respectively, the statistical significance at probability levels of $10 \%, 5 \%$ and $1 \%$.

The variables on infrastructures lose their significance in the complete model: only the PHONE variable is $10 \%$ significant in the 2SLS estimation. The significance of the variable related to inflation is also lower in the complete model than in the previous estimations. The results regarding the labour cost variable (WAGE) are noteworthy. In this model, unlike previous ones, the sign becomes negative, but since it is not significant we cannot discard the previous hypothesis. The announcement of forthcoming EU membership always has a positive effect on investors, but its impact is more restrained: the increase in FDI stock is $58 \%$ higher than in other transition countries.

In this estimation time effects are also introduced in order to grasp the temporal effects caused by agglomeration, resulting from the greater trust by investors in transition countries thanks to their acquired experience. As we can see, ceteris paribus, FDI in transition countries increases over time; in fact, all the time effects are positive, relative to the omitted year of 1995 .

The quality of the estimation of the complete model is good: the explicative variables explain $99 \%$ of the variability of the dependent variable. The inclusion of other explicative variables was not possible, because the number of observations drops abruptly, drastically reducing the degrees of freedom. A comparison between the various estimation methods by means of the Hausman test shows that the differences in the estimations of both the Prais-Winsten and the 2SLS are statistically non-significant. 
Finally, we test for unobserved effects by applying the fixed effects technique through the LSDV model, given that there are some variables which remain unvaried over time (e.g. distance). The results are reported in Table 5. Obviously, the $\mathrm{R}^{2}$ is very high, because the dummies for each country explain a significant part of the data variation. The variables of market size in per capita terms, of openness towards foreign countries, of industrial development, of infrastructures, of macroeconomic stability and of businesses taxation level are significant. The variable of market size in absolute terms is not significant. The labour cost variable, although not significant, carries a negative sign. The coefficients of single country dummies carry a negative sign and are not significant, demonstrating that there is no country specific efficiency effect in attracting FDI. In general, the estimation through the fixed effects technique is in line with previously presented estimations.

\section{Conclusions}

The aim of this work is to provide new evidences on the factors that determine the flow of FDI into transition countries. Our analysis takes into consideration the period of most intense transition and post-transition (1994-2002), when a market economy was coming into being through privatization, restructuring and re-organization. The proposed model adds to classical FDI locational determinants variables reflecting market mechanisms and market institutions.

Based on the empirical estimates our main conclusions are that, on the one hand, the classical locational FDI factors maintain their influence in the context of transition countries, and, on the other hand, that FDI distribution among these countries is largely influenced by specific market and institutional factors that reinforce the FDI inflow. These factors are, in order of significance and magnitude: the cost of labour, the real exchange rate, the physical infrastructure, the inflow of private capital, the business registration costs, the inflation rate, the diffusion of internet users, the rigidity of employment laws. In terms of policy implications these findings confirm that, to attract FDI, the now emerging economies (former transition countries), can play on different "scores", going from economic to institutional factors.

Particularly interesting there are the results regarding the influence on FDI of the cost of labour. Contrary to the common wisdom, FDI inflows are not restrained in countries that have higher wages than other transition countries. The answer to this apparent paradox can be found in the role played by other variables. A relatively higher cost of labour is often associated with the presence of economies of agglomeration, better infrastructures and a stable macroeconomic context, so that foreign firms prefer to invest in countries with these characteristics (such as the Czech Republic, Slovenia and Estonia).

As regards the institutional environment we have found that the variables representing market stabilising institutions play a more important role in attracting FDI than those representing market creating institutions. The demonstration of this tendency 
is to be found in the importance of forthcoming membership of the EU, which is a signal to foreign firms of a completed transition and of establishment of solid market institutions. This means that to attract FDI, countries need, first of all, to "consolidate" their long-run macroeconomic stability. The differences in the effects of the two types of institutions can be explained by the fact that foreign firms are able to handle microeconomic factors (such as the cost of setting up an establishment), but cannot influence macroeconomic factors (such as inflation or the exchange rate).

Our results reflect a certain tolerance on the part of foreign investors for a weak institutional environment typical of transition economies, particularly in countries rich in natural resources. However, the results also indicate that countries that want to attract more FDI need to reinforce market institutions in order to improve their macroeconomic stability.

\section{References}

Altomonte, C. (2000), "Economic Determinants and Institutional Frameworks: FDI in Economies in Transition." Transnational Corporations, Vol. 9, No 2, pp. 75-106.

Barba Navaretti, G., Venables, A. (2004), Multinational Firms in the World Economy. Princeton: Princeton University Press.

Baum, C. F., Schaffler, M. E., Stillman, S. (2003), "Instrumental Variables and GMM: Estimation and Testing." Working Paper No. 545, Boston College.

Bellak, C., Leibrecht, M. (2005), "Do Low Corporate Income Tax Rates Attract FDI? Evidence from Eight Central and East European Countries." University of Nottingham Research Paper No. 2005/43.

Bergstrand, J. (1989), "The Generalised Gravity Equation, Monopolistic Competition and the FactorProportions Theory in International Trade." Review of Economics and Statistics, Vol. 71, No. 3, pp. 143-53.

Bevan, A., Estrin, S. (2004), "The Determinants of Foreign Direct Investment into European Transition Economies." Journal of Comparative Economics, Vol. 32, No. 2, pp. 775-787.

Billington, N. (1999), "The Location of Foreign Direct Investment: an Empirical Analysis." Applied Economics, Vol. 31, No. 1, pp. 65-76.

Biswas, R. (2002), "Determinants of Foreign Direct Investment." Review of Development Economics, Vol. 6, No. 3, pp. 492-504.

Boeri, T., Terrell, K. (2002), "Institutional Determinants of Labor Reallocation in Transition." Journal of Economic Perspectives, Vol. 16, No. 1, pp. 51-76.

Brenton, P., Di Mauro, F., Lücke, M. (1999), "Economic Integration and FDI: An Empirical Analysis of Foreign Investment in the EU and in Central and Eastern Europe." Empirica, Vol. 26, No. 2, pp. 95-121.

Campos, N., Coricelli, F. (2002), "Growth in Transition: What We Know, What We Don't, and What We Should." Journal of Economic Literature, Vol. 40, No. 3, pp. 793-836.

Carstensen, K., Toubal, F. (2004), "Foreign Direct Investment in Central and Eastern European Countries: A Dynamic Panel Analysis." Journal of Comparative Economics, Vol. 32, No. 1, pp. 3-22.

Castiglione, C., Gorbunova, Y., Infante, D., Smirnova, J. (2012), "FDI Determinations in an Idiosyncratic Country. A Reappraisal Over the Russian Regions During Transition Years." Communist and Post-Communist Studies, Vol. 45, No. 1-2, pp. 1-10. 
Cheng L. K., Kwan, Y. K. (2000), "What Are the Determinants of the Location of Foreign Direct Investment? The Chinese Experience." Journal of International Economics, Vol. 51, No. 2, pp. 379-400.

Cieślik, A., Ryan, M. (2004), "Explaining Japanese Direct Investment Flows into an Enlarged Europe: A Comparison of Gravity and Economic Potential Approaches." Journal of the Japanese and International Economies, Vol. 18, No. 1, pp. 12-37.

Co, C. Y. (2000), "R\&D, Foreign Direct Investment and Technology Sourcing?" Review of Industrial Organization, Vol. 6, No. 4, pp. 385-97.

De Backer, K., Sleuwaegen, L. (2003), "Does Foreign Direct Investment Crowd out Domestic Entrepreneurship?" Review of Industrial Organization, Vol. 22, No. 1, 67-84.

De Melo, M., Denizer, C., Gelb, A., Tenev, S. (1997), "Circumstance and Choice: The Role of Initial Conditions and Policies in Transition Economies." World Bank, Working Paper WP 1866.

Demirhan, E., Masca, M. (2008), "Determinants of Foreign Direct Investments Flows to Developing Countries: a Cross-Sectional Analysis." Prague Economic Papers, Vol. 2008, No. 4, pp. 356-369.

Disdier, A. C., Mayer, Y. (2004), "How Different Is Eastern Europe? Structure and Determinants of Locational Choices by French Firms in Eastern and Western Europe." Journal of Comparative Economics, Vol. 32, No. 2, pp. 280-96.

Djankov, S, Glaeser, E. L., La Porta, R., Lopez-de-Silanes, F., Shleifer, A. (2003), "The New Comparative Economics." NBER Working Papers Series 9608.

Dunning, J. H. (1993), Multination Enterprises and the Global Economy, Harlow, Addison-Wesley.

Dunning, J. H. (1993), "The Eclectic (OLI) Paradigm of International Production: Past, Present and Future." International Journal of Economics and Business, Vol. 8, No. 2, pp. 173-190.

Esfahani, H. S., Ramirez, M. T. (2003), "Institutions, Infrastructure, and Economic Growth." Journal of Development Economics Vol. 70, No. 2, pp. 443-477.

Fabry, N, Zeghni, S. (2006), "How Former Communist Countries of Europe May Attract Inward Foreign Direct Investment? A Matter of Institutions." Communist and Post-Communist Studies, Vol. 39, No. 2, pp. 201-219.

Galeotti, E, Ryšavá, E. (2008), "The Endogeneity Problem and FDI in Transition: Evidence from the Privatized Glass Sector" Prague Economic Papers, Vol. 2008, No. 4, pp. 319-339.

Garibaldi, P., Mora, N., Sahay, R., Zettelmeyer, J. (2001), "What Moves Capital to Transition Economies?" IMF Staff Papers, Vol. 48 Special Issue.

Globerman, S., Shapiro, D. (2002), "Global Foreign Direct Investment Flows: The Role of Governance Infrastructure." World Development, Vol. 30, No. 11, pp. 1899-1919.

Holland, D., Pain, N. (1998), "The Diffusion of Innovations in Central and Eastern Europe: A Study of the Determinants and Impact of Foreign Direct Investment." NIESR Discussion Paper No. 137, London, NIESR.

Infante, D., Smirnova, J., (2009a), "Entrepreneurship, Rent-Seeking Spillovers and Decreasing Returns: A Simple Microeconomic Approach." Acta Oeconomica, Vol. 59, No. 1, 79-89.

Infante, D., Smirnova, J., (2009b), "Rent-Seeking under a Weak Institutional Environment." Economics Letters, Vol. 104, No. 3, pp. 118-121.

Infante, D., Smirnova, J., (2010), "Politicians, Firms and Institutional Environment." Seoul Journal of Economics, Vol. 23, No. 3, pp. 391-406.

Kimberly A., Cosmina L., (2005), "Re-entering Europe: Does European Union Candidacy Boost Foreign Direct Investment?" Economics of Transition, Vol. 13, No. 1, pp. 77-103.

Kinoshita, Y., Campos, N. F. (2003), "Why Does FDI Go Where It Goes? New Evidence from the Transition Economies." CEPR Discussion Paper No. 3984, London, CEPR.

Konings, J. (2000), "The Effects of Foreign Direct Investment on Domestic Firms: Evidence from Firm Level Panel Data in Emerging Economies." CEPR Discussion Paper No. 2586, London, CEPR. 
Ledyaeva, S., Linden, M. (2008), "Determinants of Economic Growth: Empirical Evidence from Russian Regions." The European Journal of Comparative Economics, Vol. 5, No. 1, pp. 87-105.

Markusen, J. R., Venables, A. J. (1998), "Multinational Firms and the New trade Theory." Journal of International Economics, Vol. 46, No. 2, pp. 183-203.

Mišun, J., Tomšík, W. (2002), "Foreign Direct Investment in Central Europe - Does It Crowd in Domestic Investment?" Prague Economic Papers, Vol. 2002, No. 1, pp. 57-66.

Oguledo, V. I., MacPhee, C. R. (1994), "Gravity Models: A Reformulation and an Applications to Discriminatory Trade Arrangements." Applied Economics, Vol. 26, No. 2, pp. 107-120.

Pastore, F. (2004), "Slow and Steady Wins the Race? An Appraisal of Ten Years of Economic Transition." Economia Politica, Vol. 21, No. 3, pp. 437-458.

Resmini, L. (1999), "The Determinants of Foreign Direct Investment into the CEECs: New Evidence from Sectoral Patterns." LICOS Discussion Paper 83, Leuven: LICOS, Centre for Transition Economies.

Rodrik, D., Subramanian, A. (2003), "The Primacy of Institutions (and what this does and does not mean)." Finance \& Development, Vol. 40, No. 2, pp. 31-34.

Smarzynska, B. K. (2002), "The Composition of Foreign Direct Investment and Protection of Intellectual Property Rights: Evidence from Transition Economies." Working Paper No. 2786, Washington, World Bank.

Smarzynska, B. K., Wei, S.-J. (2001), "Corruption and Foreign Direct Investment: Firm-Level Evidence." CEPR Discussion Paper No. 2967, London, CEPR.

Titarenko, D. (2006), "The Influence of Foreign Direct Investment on Domestic Investment Processes in Latvia." Transport and Telecommunication, Vol. 7, No. 1, pp. 76-83.

Yudaeva, K., Kozlov, K., Melentieva, N., Ponomareva, N. (2000), "Does Foreign Ownership Matter? Russian Experience." Economics of Transition, 11(3), 383-409.

Wei, S.-J. (1995), "Attracting Foreign Direct Investment: Has China Reached Its Potential?" China Economic Review, Vol. 6, No. 2, pp. 187-99. 